\title{
Benign recurrent intrahepatic cholestasis associated with pregnancy
}

\author{
Gebelikle ilişkili benign rekürren intrahepatik kolestaz
}

\section{Hari Krishan Aggarwal, Deepak Jain*, Tarana Gupta, Promil Jain, Vipin Kaverappa, Ashwani Kumar}

Department of Medicine (Prof. H. K. Aggarwal, MD, Assist. Prof. D. Jain, MD, Assist Prof. T. Gupta, MD, V. Kaverappa, MD, A. Kumar, MD), Department of Pathology (P. Jain, MD), Pt. B. D. Sharma Postgraduate Institute of Medical Sciences IN-124001 Rohtak

\begin{abstract}
Benign recurrent intrahepatic cholestasis is a rare condition which is believed to be an autosomal recessive disorder characterized by mutation in the aminophospholipid flippase gene ATP8B1 located on chromosome 18q21. It is characterized by recurrent episodes of intrahepatic cholestasis with normal gamma glutamyl transferase. We here describe a case of benign intrahepatic cholestasis associated with pregnancy.
\end{abstract}

Keywords: Benign recurrent intrahepatic cholestasis, jaundice, pregnancy

\section{Özet}

Benign rekürren inrahepatik kolestaz nadir bir durum olup 18q21 kromozomu üzerindeki aminofosfolipid flippaz geni ATP8B1'de oluşan mutasyona ikincil gelişen otozomal resesif bir hastalık olduğu düşünülmektedir. Gamma glutamil transferaz enziminin normal olduğu rekürren intrahepatik kolestaz epizotları ile karakterizedir.Burada gebelikle ilişkili bir benign intrahepatik kolestaz olgusu anlatılmıştır.

Anahtar sözcükler: Benign rekürren intrahepatik kolestaz, sarılık, gebelik

Geliş tarihi/Received: April 23, 2011; Kabul tarihi/Accepted: August 09, 2012

\section{*Corresponding author:}

Dr. Deepak Jain, Department of Medicine, 2/8 FM, Medical Campus Pt. BD Sharma PGIMS Rohtak-IN-124001 (Haryana) E-mail: hariaggarwal@ rediffmail.com

\section{Introduction}

Jaundice in pregnancy has a wide differential diagnosis including hyperemesis gravidarum (usually in first trimester), toxaemia of pregnancy and hemolysis, elevated liver enzymes, low platelet count (HELLP) syndrome (usually in third trimester), acute fatty liver of pregnancy (often in late third trimester or after delivery), intrahepatic cholestasis of pregnancy (ICP), and acute viral hepatitis or is drug induced. In benign recurrent intrahepatic cholestasis (BRIC), there occur recurrent self-limiting episodes of jaundice, pruritis with normal gamma glutamyl transferase with normal or mildly raised transaminases. We report an interesting case of BRIC associated with pregnancy.

\section{Case report}

A 22 year old female patient with pregnancy of 12 weeks duration presented to medical emergency with complaints of high grade fever without chills and rigors, loose stools, vomiting, pruritis, yellowish discolouration of eyes, and deep coloured urine for the last 2 days. Also there was history of bleeding per vaginum, decreased urine output and periorbital puffiness for one day. On physical examination, the patient had icterus, 
tachycardia (HR 120/min) and her vitals were stable. Abdominal palpation revealed fullness of lower abdomen. There was no organomegaly. Respiratory and cardiovascular systems were unremarkable. Hematological investigations revealed normal hemoglobin of $11.2 \mathrm{~g} / \mathrm{dL}$, raised total leukocyte count of $16,000 / \mathrm{mm}^{3}$ with differential leukocyte count showing 75 polymorphs, 20 lymphocytes, 3 eosinophils and 2 basophils. Platelet count was $170,000 / \mathrm{m}^{3}$ and peripheral blood smear was negative for malarial parasite. Her total serum bilirubin was $19 \mathrm{mg} / \mathrm{dL}$, in which direct fraction was $10 \mathrm{mg} / \mathrm{dL}$ and indirect was 9 $\mathrm{mg} / \mathrm{dL}$ with raised alkaline phosphatase $(550 \mathrm{U} / \mathrm{L})$ and mildly raised serum aspartate aminotransferase (116 U/L; normal 5-40 U/L) and serum alanine aminotransferase (114 U/L; normal 7-56 U/L). Gamma glutamyl transpeptidase levels were normal. Patient's renal functions were also deranged with blood urea $(184 \mathrm{mg} / \mathrm{dL})$ and creatinine (4.8mg/dL). Uric acid was $8.9 \mathrm{mg} / \mathrm{dL}$, calcium was $7.4 \mathrm{mg} / \mathrm{dL}$ (8.5-10.5), phosphorus was $5.3 \mathrm{mg} / \mathrm{dL}$ (3.5-5.5), sodium was $133 \mathrm{mEq} / \mathrm{L}$, and potassium was $4.1 \mathrm{mEq} / \mathrm{L}$.

At admission her sonogram revealed a live fetus with of 12 month gestation with no structural abnormality with adequate liquor. There was no abnormality in kidneys and liver was normal with non-dilated intrahepatic and extrahepatic ducts. Markers for infective viral hepatitis including HBsAg, Anti-HCV, IgM anti HAV, IgM anti HEV were negative. No evidence of diffuse intravascular coagulopathy and intravascular hemolysis was found and prothrombin time, activated partial thromboplastin time, international normalized ratio (INR), fibrinogen degradation products, and serum haptoglobin were normal. VDRL (Venereal Disease Research Laboratory test), TORCH (Toxoplasma, Others, Rubella, Cytomegalovirus, Herpes simplex virus) and antiphospholipid antibody (APLA) were negative. Urine examination was normal.

Repeat sonogram two days later showed absent fetal cardiac activity so dilatation and evacuation was done. Patient was treated as a case of septicemia with acute renal failure and liver dysfunction in first trimester. Patient was given broad antibiotic coverage. Hemodialysis was done for 9 sessions and renal functions improved subsequently. Serum bilirubin levels started decreasing. Tests for human immunodeficiency virus HIV-1, HIV2 , and markers for autoimmune hepatitis including antinuclear antibodies (ANA), pANCA, antimicrosomal antibodies (AMA), anti-LKM1, anti-smooth muscle antibody, and anti-ds DNA were negative.

The patient revealed a past history of spontaneous first trimester abortion about 8 months back. She had jaundice at that time also from which she recovered completely. She also revealed intermittent episodes of mild attacks of jaundice during childhood which was uncomplicated. Medical records of those previous episodes were not available. She had no significant history of any other chronic disease. The patient did not give any history of intake of oral contraceptive pills and any other drug. No similar family history to suggest recurrent episodes of jaundice could be elicited.

At follow up after 4 months, the patient's serum bilirubin levels declined but remained above normal (total $2 \mathrm{mg} / \mathrm{dL}$, direct $1.5 \mathrm{mg} / \mathrm{dL}$ and indirect $0.5 \mathrm{mg} / \mathrm{dL}$ ) and alkaline phosphatase levels (300 U/L). In view of deranged liver functions, liver biopsy was done keeping in view recurrent attacks of jaundice. It revealed mild intrahepatic cholestasis with intact sinusoidal pattern of hepatic cords and normal lobular architecture with mild lymphocytic infiltrate in occasional portal tract. There was no evidence of fatty change/portal tract fibrosis/hepatitis. Findings were consistent with benign recurrent intrahepatic cholestasis. (Figure 1) Genetic analysis could not be performed due to patient's unwillingness. 


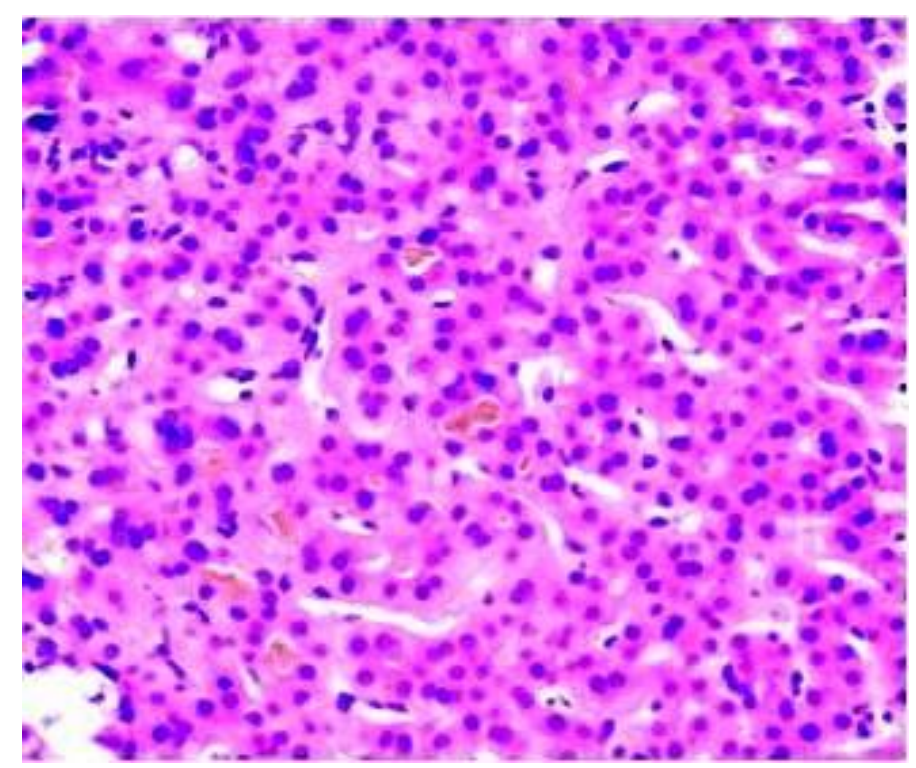

Figure 1. Liver Biopsy showing features of benign recurrent intrahepatic cholestasis $(\mathbf{H} \&$ E).

\section{Discussion}

Benign recurrent intrahepatic cholestasis (BRIC) was described by Summerskill and Walshe [1] in 1959 as recurrent episodes of jaundice and pruritus. The disorder is believed to be an autosomal recessive disorder characterised by mutation in the aminophospholipid flippase gene ATP8B1 located on chromosome 18q21. It is characterized by intermittent episodes of cholestasis with normal extrahepatic biliary tree. The attacks can start at any age and last for weeks to months. The intensity and length of diseased periods vary unpredictably before resolving spontaneously [2]. Patients are completely asymptomatic for months to years between symptomatic periods. The diagnosis of BRIC can be confirmed only after exclusion of other possible congenital or acquired causes of intrahepatic cholestasis in view of recurrent episodes of jaundice. Exacerbation of an episode of BRIC with pregnancy has been reported [3]. The cholestasis is preceded by intense pruritus, malaise, and lassitude and occasionally by erythematous rash. The hallmark of disease is cholestasis - elevated biliribin, bile acids and alkaline phosphatase with normal gamma glutamyl transpeptidase (GGT). Liver function tests are normal between bouts. In BRIC, the alkaline phosphatase is usually elevated 5-10 times while the bilirubin levels are moderately increased up to $5 \mathrm{mg} / \mathrm{dl}$; sometimes even higher levels are present. The transaminases are usually in normal range but can increase up to 200-400 U/L [4]. The disease follows a benign course and there is no progression to cirrhosis [5]. However, a case report has revealed that some patients initially presenting with clinical features of BRIC may later progress to progressive familial intrahepatic cholestasis. The later condition may progress to cirrhosis and liver failure, which mandates a regular follow up for a patient of BRIC [6].

The differential diagnosis of liver function abnormalities during pregnancy is extensive and includes i) diseases that are not primarily associated with gestation, such as hepatitis, biliary tract diseases, drug induced, and ii) diseases related to pregnancy which include hyperemesis gravidarum (first trimester), toxaemia of pregnancy and HELLP syndrome (third trimester), acute fatty liver of pregnancy (often late third trimester or soon after delivery) and intrahepatic cholestasis of pregnancy [7]. Our patient had sepsis during pregnancy which may also cause jaundice, but it is usually reversible and resolves with in few weeks. Our patient continued to have abnormal liver function tests even after 4 months and so sepsis was excluded as a cause. Intrahepatic cholestasis of pregnancy occurs in late second and third trimester of pregnancy in both primiparous and 
multiparous women and resolves after delivery. It can recur in subsequent pregnancies and is more common in multiple gestations, with a family history of intrahepatic cholestasis of pregnancy and in those with a history of cholestasis due to the use of oral contraceptives or exogenous estrogen [8].

Therefore having excluded other important causes of jaundice in first trimester of pregnancy, a classical history of recurrent episodes of jaundice, mild liver function abnormalities associated with sepsis and pregnancy supported with the histopathological findings, and similar episode in previous gestation and during childhood, we propose the diagnosis of benign recurrent intrahepatic cholestasis exacerbated with sepsis and gestation. Liver biopsy proves to be very significant in making diagnosis as it shows characteristic preserved lobular architecture, marked cholestasis within hepatocytes with some portal inflammation.

\section{References}

1. Summerskill WH, Walshe JM. Benign recurrent intrahepatic "obstructive" jaundice. Lancet 1959; 2: 686-90.

2. Aggarwal HK, Gupta A, Lamba A. Benign recurrent intrahepatic cholestasis. JIACM 2008; 9: 306-7.

3. Everson GT. Preexisting and pregnancy indused liver disorders (online) 1998. Article available form URL: www.medscape.com/viewarticle/722320_2 (Accesed on December 06, 2012).

4. Sasaki KJ, Peterson E. Pregnancy and Liver disorder (online).2009 (cited 2009 Aug19); Available from URL:http://emedicine.medscape.com/a/188143 (Accesed on December 06, 2012).

5. Gupta V, Kumar M, Bhatia BD. Benign recurrent intrahepatic cholestasis. Indian J Pediatr 2005; 72: 793-4.

6. van Ooteghem NA, Klomp LW, van Berge-Henegouwen GP, Houwen RH. Benign recurrent intrahepatic cholestasis progressing to progressive familial intrahepatic cholestasis: low GGT cholestasis is a clinical continuum. J Hepatol 2002; 36: 439-43.

7. den Dulk M, Valentijn RM, Welten CA, Beyer GP.Intrahepatic cholestasis of pregnancy. The Neth J Med 2002; 60: 366-9.

8. Muresan D, Ona D, Cruciat G, Rotar I, Stamatian F. Recurrent Intrahepatic Cholestasis of Pregnancy. A Case Report. J Gastrointestin Liver Dis 2008; 17: 323-5. 